\title{
The content of available macro- and microelements against the background of enzymatic activity in soils affected by the soda industry
}

\author{
Agata Bartkowiak*, Joanna Lemanowicz \\ UTP University of Science and Technology in Bydgoszcz, Faculty of Agriculture and Biotechnology, Department Biogeochemistry and Soil Science, \\ 6 Bernardyńska St. 85-029 Bydgoszcz, Poland
}

* A. Bartkowiak, bartkowiak@utp.edu.pl, ORCID iD: https://orcid.org/0000-0003-2535-0085

Received: 29.05 .2020

Accepted: 05.08.2020

Associated editor: B. Rutkowska

\section{Keywords}

Enzymatic activity

Available macroelements

and microelements

Technogenic soils

Salt affected soils

\begin{abstract}
Salinity is one of the main causes of degradation in the soil environment. The long-term salinity affects the properties physicochemical and activity of the biological parameters in soil considerably. The aim in the study was to assess the content of selected macro- and microelements and enzymatic properties in soils in areas adjacent to the soda plant. The research was conducted in the area adjacent to the CIECH Soda Polska S.A. in Inowrocław. This study presents an assessment of the content of selected bioavailable macroelements $(\mathrm{P}, \mathrm{K}, \mathrm{Mg}$ ) and microelements $\mathrm{Zn}, \mathrm{Cu}, \mathrm{Mn}$, Fe) against the background of the enzymatic activity (dehydrogenases, catalase, peroxidase, and alkaline and acid phosphatase) of soil. The soil was sampled from surface mineral horizon (0-30 $\mathrm{cm}$ deep). Seven sites were selected for soil sampling (S1-S6 on the grounds of a soda plant, and area $\mathrm{C}$ - the control). The effect of long-term salinity on the studied soil properties was found. The content of available macro- and micronutrients varied significantly depending on the soil sampling site. The presented results did not show unidirectional changes in the content of available $\mathrm{P}, \mathrm{K}, \mathrm{Mg}$, $\mathrm{Zn}, \mathrm{Cu}, \mathrm{Mn}$ and $\mathrm{Fe}$, nor in the activity of dehydrogenases, catalase, peroxidase, or alkaline and acid phosphatases in the technogenic soil. In the analysed soil samples, contents of the bioavailable forms of all the tested microelements were found to be low. The activity of the tested enzymes was found to be lowest in soil from S6 (in the vicinity of waste dumping sites, a sewage treatment plant and the soda plant).
\end{abstract}

\section{Introduction}

Soils are salinated through complex processes that can be caused by the natural accumulation of salt in the soil or by inappropriate human activity (Zhou et al., 2012). In the temperate climate zone, salt-affected soils are formed under the impact of salt springs during natural soil-forming processes (Piernik and Hulisz, 2011), and also due to anthropogenic saline habitats. The problem is anthropogenic salinity, which mainly relates to large industrial centres established near to natural mineral deposits. It is also associated with mining waste dumps and areas around soda industry plants (Cieśla et al., 1981; Hulisz and Piernik, 2013), the use of mineral salts for de-icing roads (Daliakopoulos et al., 2016) and the intensive use of mineral fertilisers (Widłak, 2016). Salination can affect high-class arable soils of high utility value. This occurs because an excess of sodium ions negatively affects soil structure, aggregate stability and soil hydraulic properties. High sodium concentrations degrade soil through the dispersion of clay and slaking. This can affect water and air movement and root penetration (Crescimanno et al., 1995). Salt toxicity is one of the major edaphic factors limiting plant growth (Khatar et al., 2017). Natural and induced soil salinity reduce plant growth and the activity of microorganisms by lowering water availability (as a result of the high osmotic potential of the soil solution) and by raising ion toxicity (Wang et al., 2013). High concentrations of salts may also change the chemical behaviour of metals accumulated in soils, increasing or decreasing their availability. The method of soil use also affects the content of macro- and microelements by changing the physics, chemistry and biology of the soil. Longterm salinity can considerably degrade the parameters of soil biological activity. That is why, in recent years, enzyme activity testing has been used to assess soil fertility. For several years there has been a progressive devastation of arable soils in the immediate vicinity of the waste tanks of the CIECH Soda Polska S.A. plant in Mątwy (Hulisz et al., 2018; Lemanowicz, 2019; Bartkowiak et al., 2020). The infiltration of collected waste water into the ground is increasing the salinity and alkalinity of adjacent soils.

This study aims to assess the content of selected macro- and microelements and enzymatic properties in soils in areas adjacent to the soda plant. 


\section{Material and methods}

\subsection{Location of soil sampling}

The research was conducted in the area adjacent to $\mathrm{CIECH}$ Soda Polska S.A. (a soda plant founded in 1882) in Inowrocław. The soda factory produces, for example, light and heavy soda ash, sodium bicarbonate, calcium chloride, and precipitated calcium carbonate. The soil was sampled from the mineral horizon (0-30 cm deep) in summer (July) of 2017 at seven sites within the soda plant and from a control point (Fig. 1). The sites differed in their method of use: site S1 - places around the clarifying-cooling "pond", where carbonates are precipitated as waste (a non-reclaimed location); sites S2 and S3 - places where technical and agrotechnical reclamation have been completed; site S4 - a dried pond for ash waters; site S5 - an agricultural field where spring barley was grown $500 \mathrm{~m}$ from the soda plant; and site S6 - places in the vicinity of waste dumping sites, a sewage treatment plant and the soda plant with numerous communities of halophytes.

\subsection{Soil analysis}

In the air-dried soil samples with a disturbed structure and sieved through ř 2-mm mesh, the following physicochemical properties were determined: clay fraction by laser diffraction using a Mastersizer MS 2000 analyser; $\mathrm{pH}$ in $0.01 \mathrm{M} \mathrm{CaCl}_{2}$ measured potentiometrically (PN-ISO 10390, 1997); total organic carbon (TOC) using a TOC FORMACTS ${ }^{\mathrm{TM}}$ Primacs analyser provided by Skalar; electrical conductivity (ECe) in soil paste; and total exchangeable bases (TEB) by the Kappen method (Soil Survey Investigation, 1996). Additionally, the contents of available forms of $\mathrm{Zn}, \mathrm{Cu}, \mathrm{Mn}$ and Fe extracted with DTPA solution were assayed according to Lindsay and Norvell (1978). The contents of available forms of phosphorus (P) (PN-R-04023, 1996), potassium (K) were also defined, by the Egner-Riehm method (DL) (PN$\mathrm{R}-04022$, 1996), as was the content of magnesium available to plants (Mg) following the Schachtschabel method (PN-R-04020, 1994). The content of forms available to plants was determined by atomic absorption spectroscopy and atomic emission spectroscopy using a PU 9100X (Philips) spectrometer. To verify the adequacy of the results and the accuracy of the measurement, the certified material Loam Soil No. ERM-CC141 was analysed, and so-called null tests were performed according to the same analytical procedure as the investigated soil material.

The activity of selected oxidoreductase and hydrolytic enzymes was assayed: dehydrogenases (DEH) in soil by the Thalmann method (1968), catalase (CAT) by the Johnson and Temple method (1964), peroxidases (PER) by the Bartha and Bordeleau method (1969), and alkaline (AlP) and acid (AcP) phosphatase by the Tabatabai and Bremner method (1969).

\subsection{Statistical analysis}

The results were analysed statistically using STATISTICA 13.0 software. The data were analysed by one-way ANOVA variance analysis, followed by Tukey's post-hoc test, which isolated homogeneous groups. Significant differences $(p<0.05)$ were studied further. All analytical measurements were performed in three replicates. Arithmetic mean values are shown in tables,

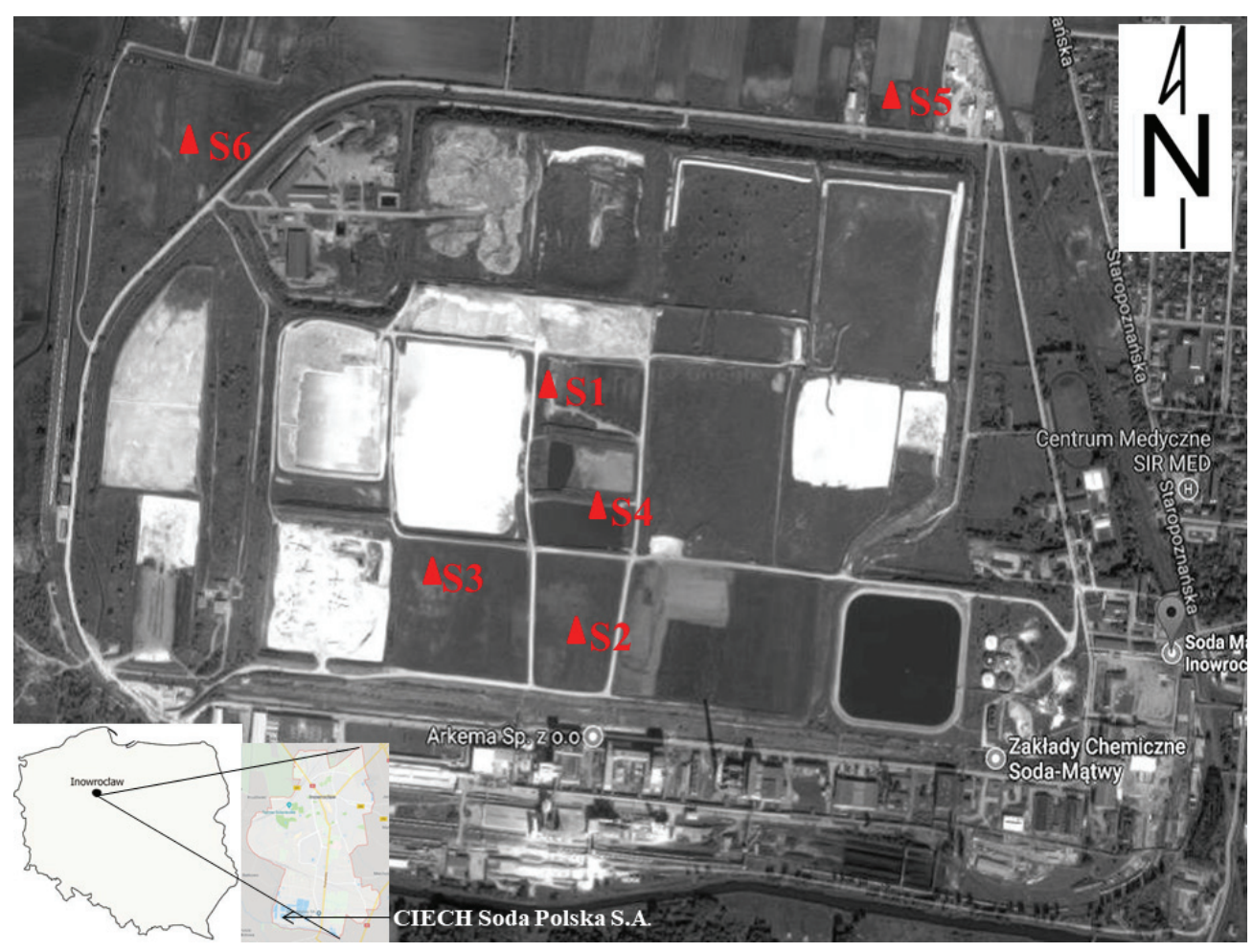

Fig. 1. Location of the study area 
including standard deviation $( \pm S D)$. The analysis results were analysed for simple correlation ( $p<0.05)$, which determined the degree of dependence between respective features. The precision and accuracy of the analyses was determined using certified reference material (Loam Soil No. ERM-CC141).

\section{Results and discussion}

According to the Polish Soil Classification (2019), the tested soils are Anthropogenic soils degraded as a result of technologically induced salination, and can be classified as Industriosols. Selected physical and chemical soil properties are presented in Table 1. The soil pH values ranged from 6.78 to 7.65 (which is characterised as neutral and alkaline) and clay content ranged from 4.8 to $9.0 \%$. Total exchangeable bases (TEB) were at low levels. Total exchangeable bases in soil varied significantly by soil sampling site. The highest TEB values were highest in the soil of S6 (51.63 mmol(+) $\left.\cdot \mathrm{kg}^{-1}\right)$, but no significant differences in TEB were found in soil sampled from S1-S4 (Table 1).

Total organic carbon content varied depending on the studied habitat, ranging from 2.36 to $77.02 \mathrm{~g} \cdot \mathrm{kg}^{-1}$. The highest content of TOC was determined in the soil from the S1 site and the lowest in the S6 and control soil. Salt-affected soils usually have low organic matter contents due to insufficient plant growth leading to low inputs of organic materials. According to Wong et al. (2010), in saline soils there are a number of opposing processes, some of which often inhibit the humification process. Salinity measured by electrical conductivity varied from 10.1 to $60.5 \mathrm{dS} \cdot \mathrm{m}^{-1}$. Similar results were obtained by Hulisz et al. (2018). The highest conductivity was detected for sample S6, having been under the impact of three sources of salinity: the sedimentation tanks, the sewage treatment plant and the municipal waste dump. Most of the soils were, according to Jackson's (1958) classification, very strongly saline $\left(\mathrm{ECe}>16 \mathrm{dS} \cdot \mathrm{m}^{-1}\right)$.

The content of bioavailable elements in the studied soil profiles ranged from 5.58 to $128.00 \mathrm{mg} \cdot \mathrm{kg}^{-1}$ for phosphor, 40.9 to $310.0 \mathrm{mg} \cdot \mathrm{kg}^{-1}$ for potassium, and 121.0 to $590.5 \mathrm{mg} \cdot \mathrm{kg}^{-1}$ for magnesium (Table 2). The content of available macronutrients var- ied significantly depending on the soil sampling site. The highest contents of $\mathrm{P}$ and $\mathrm{K}$ were recorded for the control (C) and the highest Mg was in S3 (soil where technical and agrotechnical reclamation had been conducted). ANOVA showed that contents were by far the lowest at S6 for P and $\mathrm{Mg}$, and at S3 for $\mathrm{K}$. No significant differences in $\mathrm{P}$ content were found between soils sampled from S1, S2, S4 and S5. The content of P was significantly negatively correlated with ECe $(r=0.834, p=0.019)$ and $\mathrm{pH}$ $(\mathrm{r}=0.860, \mathrm{p}=0.013)$. The variation in available phosphorus in the soil was $69.9 \%$ determined by ECe and $73.9 \%$ by $\mathrm{pH}$ (Table 5 ). The toxic effect of soil salinity may increase in the presence of chlorides, dramatically reducing absorption of nutrients (mainly of N, P and K). Available phosphorus was positively correlated with acid phosphatase activity $(r=0.905, p=0.005)$. Variation in phosphorus was found (using the value of the coefficient of determination $\left[R^{2}\right]$ ) to account for as much as $82 \%$ of the variation in the activity of AcP. The linear regression equations shows that with a $1 \mathrm{~g} \cdot \mathrm{kg}^{-1}$ increase in AP the activity of AlP increase by $29 \mathrm{mM} \mathrm{pNP} \cdot \mathrm{kg}^{-1} \cdot \mathrm{h}^{-1}$ (Table 5). According to Choudhary and Yaduvanshi (2016) saline soils often contain medium to high amounts of available K. However, during reclamation, $\mathrm{K}$ may be lost due to leaching, leading to its low availability. But Xie et al., (2019) stated that long-term reclamation could radically decrease soil salination and promote soil nutrient accumulation (SOM, TN, TP, AN, AP, CEC).

In the analysed soils the content of available $\mathrm{Zn}, \mathrm{Cu}, \mathrm{Mn}$ and Fe forms fell by the following ranges of values: $\mathrm{Zn}-0.89-13.94$ $\mathrm{mg} \cdot \mathrm{kg}^{-1} ; \mathrm{Cu}-0.75-5.69 \mathrm{mg} \cdot \mathrm{kg}^{-1} ; \mathrm{Mn}-3.38-5.24 \mathrm{mg} \cdot \mathrm{kg}^{-1}$; and Fe - 2.88-28.06 $\mathrm{mg} \cdot \mathrm{kg}^{-1}$ (Table 3).

The highest content of zinc available to plants was noted at sites C, S2 and S3, and at those points it was higher than the content specified as a deficit for plants; namely, $0.8 \mathrm{mg} \cdot \mathrm{kg}^{-1}$ (Lindsay and Norvell, 1978). Alkali soils usually contain less than $0.6 \mathrm{mg}$ DTPA-extractable $\mathrm{Zn}$ per $\mathrm{kg}$ of soil and show a marked deficiency of this element (Choudhary and Yaduvanshi, 2016). Meanwhile, the content of copper extracted with DTPA, which is considered to be the content available to plants, exceeded the deficit contents below which plants' growth and yield worsen; namely, 0.12-0.25 $\mathrm{mg} \cdot \mathrm{kg}^{-1}$ (Sims and Johnson, 1991). However,
Table 1

The content of clay [\%], $\mathrm{pH}$ in $\mathrm{CaCl}_{2}$, total organic carbon (TOC) $\left[\mathrm{g} \cdot \mathrm{kg}^{-1}\right]$, ECe [dS $\cdot \mathrm{m}^{-1}$ ] and TEB $\left[\mathrm{mmol}(+) \cdot \mathrm{kg}^{-1}\right]$

\begin{tabular}{llllll}
\hline Sites & Clay & pH & TOC & ECe & TEB \\
\hline C & 9.00 & 6.78 & $2.36^{\mathrm{c}} \pm 0.20$ & $10.1^{\mathrm{c}} \pm 0.57$ & $30.42^{\mathrm{d}} \pm 1.77$ \\
S1 & 7.94 & 7.47 & $77.02^{\mathrm{a}} \pm 26.98$ & $36.5^{\mathrm{b}} \pm 8.49$ & $48.81^{\mathrm{b}} \pm 0.51$ \\
S2 & 7.52 & 7.43 & $9.06^{\mathrm{c}} \pm 1.99$ & $17.6^{\mathrm{c}} \pm 2.97$ & $49.60^{\mathrm{b}} \pm 0.07$ \\
S3 & 5.60 & 7.44 & $8.38^{\mathrm{c}} \pm 0.36$ & $18.1^{\mathrm{c}} \pm 3.96$ & $49.84^{\mathrm{b}} \pm 0.10$ \\
S4 & 6.61 & 7.41 & $33.24^{\mathrm{b}} \pm 20.39$ & $20.6^{\mathrm{c}} \pm 0.07$ & $49.78^{\mathrm{b}} \pm 0.09$ \\
S5 & 4.80 & 7.22 & $28.7^{\mathrm{b}} \pm 0.77$ & $34.6^{\mathrm{b}} \pm 1.63$ & $39.05^{\mathrm{c}} \pm 0.16$ \\
S6 & 6.61 & 7.65 & $2.36^{\mathrm{c}} \pm 2.08$ & $60.5^{\mathrm{a}} \pm 2.12$ & $51.63^{\mathrm{a}} \pm 0.51$ \\
\hline
\end{tabular}

Values followed by the same letter are not significantly different at $p<0.05$. Different small letters indicate comparison between sites. ( \pm )Standard Deviation
Table 2

The content of available phosphorus (P) $\left[\mathrm{mg} \cdot \mathrm{kg}^{-1}\right]$, potassium (K) $\left[\mathrm{mg}^{\mathrm{kg}} \mathrm{kg}^{-1}\right]$ and magnesium $(\mathrm{Mg})\left[\mathrm{mg} \cdot \mathrm{kg}^{-1}\right]$

\begin{tabular}{llll}
\hline Sites & $\mathrm{P}$ & $\mathrm{K}$ & $\mathrm{Mg}$ \\
\hline $\mathrm{C}$ & $128.0^{\mathrm{a}} \pm 24.04$ & $310.0^{\mathrm{a}} \pm 1.41$ & $174.0^{\mathrm{d}} \pm 15.56$ \\
S1 & $55.69^{\mathrm{c}} \pm 5.40$ & $278.5^{\mathrm{b}} \pm 3.54$ & $250.0^{\mathrm{c}} \pm 12.73$ \\
S2 & $56.32^{\mathrm{c}} \pm 9.65$ & $177.5^{\mathrm{d}} \pm 9.19$ & $391.0^{\mathrm{b}} \pm 8.49$ \\
S3 & $88.87^{\mathrm{b}} \pm 29.8$ & $40.9^{\mathrm{e}} \pm 1.94$ & $590.5^{\mathrm{a}} \pm .9 .19$ \\
S4 & $51.50^{\mathrm{c}} \pm 19.4$ & $111.5^{\mathrm{c}} \pm 9.19$ & $128.5^{\mathrm{e}} \pm 9.19$ \\
S5 & $61.10^{\mathrm{c}} \pm 8.61$ & $240.5^{\mathrm{c}} \pm 6.36$ & $150.0^{\mathrm{de}} \pm 1.41$ \\
S6 & $5.58^{\mathrm{d}} \pm 2.84$ & $150.5^{\mathrm{d}} \pm 10.61$ & $121.0^{\mathrm{e}} \pm 8.49$ \\
\hline
\end{tabular}


Table 3

The content of available zinc (Zn), copper (Cu), manganese (Mn) and iron (Fe) [mg. $\left.\mathrm{kg}^{-1}\right]$

\begin{tabular}{lllll}
\hline Sites & Zn & $\mathrm{Cu}$ & $\mathrm{Mn}$ & $\mathrm{Fe}$ \\
\hline $\mathrm{C}$ & $11.38^{\mathrm{a}} \pm 1.41$ & $1.37^{\mathrm{b}} \pm 0.10$ & $5.24^{\mathrm{a}} \pm 0.32$ & $2.88^{\mathrm{c}} \pm 0.34$ \\
$\mathrm{~S} 1$ & $0.89^{\mathrm{b}} \pm 0.00$ & $0.75^{\mathrm{b}} \pm 0.06$ & $3.38^{\mathrm{c}} \pm 0.03$ & $3.61^{\mathrm{c}} \pm 1.71$ \\
$\mathrm{~S} 2$ & $13.94^{\mathrm{a}} \pm 3.51$ & $5.36^{\mathrm{a}} \pm 2.82$ & $4.35^{\mathrm{bc}} \pm 0.33$ & $28.06^{\mathrm{ab}} \pm 2.01$ \\
S3 & $10.32^{\mathrm{ab}} \pm 2.93$ & $5.69^{\mathrm{a}} \pm 0.39$ & $4.70^{\mathrm{b}} \pm 0.11$ & $29.12^{\mathrm{a}} \pm 7.13$ \\
S4 & $1.59^{\mathrm{b}} \pm 0.9$ & $1.66^{\mathrm{b}} \pm 0.04$ & $4.87^{\mathrm{b}} \pm 0.06$ & $18.04^{\mathrm{ab}} \pm 8.26$ \\
S5 & $4.46^{\mathrm{b}} \pm 0.62$ & $1.69^{\mathrm{b}} \pm 0.16$ & $4.72^{\mathrm{b}} \pm 0.20$ & $16.96^{\mathrm{b}} \pm 2.04$ \\
$\mathrm{~S} 6$ & $4.40^{\mathrm{b}} \pm 1.77$ & $0.81^{\mathrm{b}} \pm 0.21$ & $5.04^{\mathrm{ab}} \pm 0.17$ & $22.26^{\mathrm{ab}} \pm 1.70$ \\
\hline
\end{tabular}

we should note that various plant species differ in their nutritional requirements. Therefore, the content of absorbable forms of copper in the tested soil samples was above deficiency levels. In turn, the levels of bioavailable forms of manganese found can be considered insufficient for the nutritional requirements of plants. Critical levels for DTPA-extractable Mn range from 2.5 to $5.0 \mathrm{mg} \cdot \mathrm{kg}^{-1}$ (Moraghan and Mascagni, 1991). Finally, low contents of bioavailable iron were also found in the analysed soil samples. There is a significant negative correlation between iron content and potassium content $(r=0.839$, $\mathrm{p}=0.018$ ) (Table 5).

The phyto-availability of elements is affected by: reaction; granulometric and mineral soil composition; water properties; and organic matter content. A factor limiting the solubility of most metals, and therefore their availability to plants is, alongside $\mathrm{pH}$, the amount of organic matter. In the case of copper, manganese and zinc, increased organic matter content causes them to bind strongly to the organic substance and lowers their bioavailability to plants. In contrast, in humic soils, iron forms chelate bonds that are water-soluble. Unlike the other elements mentioned, iron is easily taken up by plants (Łukasiewicz, 2012). The available forms of zinc, copper and iron were not found to correlate statistically significantly with content of total organic carbon or soil $\mathrm{pH}$. The only significant correlation found was a negative one between the content of available manganese and TOC $(r=0.839, \mathrm{p}=.018)$ (Table 5).
ANOVA indicated that the activities of the studied enzymes were dependent on the soil sampling site $(\mathrm{p}<0.05)(\mathrm{Ta}-$ ble 4). The lowest activities of DEH $\left(0.737 \mathrm{mg}\right.$ TPF $\left.\cdot \mathrm{kg}^{-1} \cdot 24 \mathrm{~h}^{-1}\right)$, CAT (0.145 mg $\left.\mathrm{H}_{2} \mathrm{O}_{2} \cdot \mathrm{kg}^{-1} \cdot \mathrm{h}^{-1}\right)$ PER (0.428 mM PPG $\left.\cdot \mathrm{kg}^{-1} \cdot \mathrm{h}^{-1}\right)$, AlP ( $\left.0.269 \mathrm{mM} \mathrm{pNP} \cdot \mathrm{kg}^{-1} \cdot \mathrm{h}^{-1}\right)$ and AcP $\left(0.448 \mathrm{mM} \mathrm{pNP} \cdot \mathrm{kg}^{-1} \cdot \mathrm{h}^{-1}\right)$ were reported in soil from site $\mathrm{S} 6$ (the location near city waste dumps, the sewage treatment plant and the soda plant). Similar results were obtained by Lemanowicz (2019). According to Telesiński (2012), increased salt content in soil decreases enzymatic activity. Osmotic potential is changed by the toxicity of specific ions and the drying of enzymatic proteins. However, this study showed no correlation between enzyme activity and salinity (ECe). The highest activity of dehydrogenases $(3.743 \mathrm{mg}$ TPF. $\left.\mathrm{kg}^{-1} \cdot 24 \mathrm{~h}^{-1}\right)$ and alkaline phosphatase $\left(2.349 \mathrm{mM} \mathrm{pNP} \cdot \mathrm{kg}^{-1} \cdot \mathrm{h}^{-}\right.$ $\left.{ }^{1}\right)$ was found in soil from S5. The activities of catalase $(0.288 \mathrm{mg}$ $\mathrm{H}_{2} \mathrm{O}_{2} \cdot \mathrm{kg}^{-1} \cdot \mathrm{h}^{-1}$ ) and acid phosphatase (3.842 mM pNP. $\left.\mathrm{kg}^{-1} \cdot \mathrm{h}^{-1}\right)$ were much the highest in the control soil (C). Peroxidase activity was highest in S3. According to Pan et al. (2013), salinity affects the enzymatic activity of soil in different ways (depending on enzyme type and degree of salinity.)

The research showed significant positive correlations between dehydrogenases and alkaline phosphatase $(r=0.826$, $\mathrm{p}=0.022)$, between catalase and acid phosphatase $(\mathrm{r}=0.805$, $\mathrm{p}=0.028)$ and between peroxidases and alkaline phosphatase $(\mathrm{r}=0.839, \mathrm{p}=0.018$ ) (Table 5). This indicates that any enzyme activity can considerably reflect other enzyme activities in soil

Table 4

The activity of dehydrogenases (DEH) [mg TPF $\left.\cdot \mathrm{kg}^{-1} \cdot 24 \mathrm{~h}^{-1}\right]$, catalase (CAT) [mg $\mathrm{H}_{2} \mathrm{O}_{2} \cdot \mathrm{kg}^{-1} \cdot \mathrm{h}^{-1}$, peroxidase (PER) [mM PPG $\left.\cdot \mathrm{kg}^{-1} \cdot \mathrm{h}^{-1}\right]$, alkaline (AlP) and acid (AcP) phosphatase $\left[\mathrm{mMpNP} \cdot \mathrm{kg}^{-1} \cdot \mathrm{h}^{-1}\right]$

\begin{tabular}{llllll}
\hline Sites & DEH & CAT & PER & AlP & AcP \\
\hline C & $1.724^{\mathrm{c}} \pm 0.10$ & $0.288^{\mathrm{a}} \pm 0.004$ & $0.736^{\mathrm{d}} \pm 0.010$ & $1.599^{\mathrm{b}} \pm 0.011$ & $3.842^{\mathrm{a}} \pm 0.953$ \\
S1 & $2.710^{\mathrm{b}} \pm 0.24$ & $0.237^{\mathrm{bc}} \pm 0.001$ & $0.884^{\mathrm{c}} \pm 0.011$ & $1.563^{\mathrm{b}} \pm 0.088$ & $1.898^{\mathrm{bc}} \pm 0.756$ \\
S2 & $2.634^{\mathrm{bc}} \pm 0.07$ & $0.232^{\mathrm{bc}} \pm 0.026$ & $1.142^{\mathrm{b}} \pm 0.047$ & $1.657^{\mathrm{b}} \pm 0.225$ & $1.729^{\mathrm{c}} \pm 0.806$ \\
S3 & $1.845^{\mathrm{c}} \pm 0.13$ & $0.204^{\mathrm{bc}} \pm 0.006$ & $1.396^{\mathrm{a}} \pm 0.013$ & $1.729^{\mathrm{b}} \pm 0.161$ & $2.434^{\mathrm{b}} \pm 0.956$ \\
S4 & $1.701^{\mathrm{c}} \pm 0.19$ & $0.194^{\mathrm{c}} \pm 0.012$ & $0.595^{\mathrm{e}} \pm 0.009$ & $0.412^{\mathrm{c}} \pm 0.210$ & $0.318^{\mathrm{d}} \pm 0.050$ \\
S5 & $3.743^{\mathrm{a}} \pm 0.30$ & $0.250^{\mathrm{ab}} \pm 0.008$ & $1.231^{\mathrm{b}} \pm 0.034$ & $2.349^{\mathrm{a}} \pm 0.206$ & $1.596^{\mathrm{c}} \pm 0.243$ \\
S6 & $0.737^{\mathrm{d}} \pm 0.02$ & $0.145^{\mathrm{d}} \pm 0.006$ & $0.428^{\mathrm{f}} \pm 0.022$ & $0.269^{\mathrm{c}} \pm 0.044$ & $0.448^{\mathrm{d}} \pm 0.055$ \\
\hline
\end{tabular}


Table 5

Relationship between selected soil properties

\begin{tabular}{|c|c|c|c|c|c|}
\hline \multicolumn{2}{|l|}{ Variables } & \multirow{2}{*}{ Equation } & \multirow{2}{*}{$r$} & \multirow{2}{*}{$R^{2}$} & \multirow{2}{*}{$p$} \\
\hline Dependent & Independent & & & & \\
\hline CAT & $\mathrm{P}$ & $y=0.1579+0.001 x$ & 0.814 & 0.663 & 0.025 \\
\hline AcP & $\mathrm{P}$ & $y=-0.1006+0.029 x$ & 0.905 & 0.820 & 0.005 \\
\hline $\mathrm{P}$ & $\mathrm{pH}$ & $y=914.71-115.87 x$ & -0.860 & 0.739 & 0.013 \\
\hline $\mathrm{P}$ & ECe & $y=115.58-1.8295 x$ & -0.834 & 0.696 & 0.019 \\
\hline K & $\mathrm{Fe}$ & $y=317.64-7.5593 x$ & -0.839 & 0.704 & 0.018 \\
\hline $\mathrm{Mg}$ & $\mathrm{Cu}$ & $y=75.89+73.498 x$ & 0.892 & 0.796 & 0.006 \\
\hline Mn & TOC & $y=5.0555-0.0192 x$ & -0.839 & 0.704 & 0.018 \\
\hline $\mathrm{DEH}$ & AlP & $y=0.709+1.0577 x$ & 0.826 & 0.682 & 0.022 \\
\hline CAT & $\mathrm{AcP}$ & $y=0.1675+0.0606 x$ & 0.805 & 0.649 & 0.028 \\
\hline CAT & $\mathrm{pH}$ & $y=1.251-0.1403 x$ & -0.855 & 0.731 & 0.014 \\
\hline CAT & TEB & $y=0.4367-0.0047 x$ & -0.815 & 0.664 & 0.025 \\
\hline PER & AlP & $y=0.3332+0.3966 x$ & 0.839 & 0.704 & 0.018 \\
\hline $\mathrm{AcP}$ & $\mathrm{pH}$ & $y=26.620-3.3868 x$ & -0.784 & 0.616 & 0.036 \\
\hline
\end{tabular}

(Lemanowicz, 2019). The activity of the enzymes was not found to significantly correlate with TOC. This may be due to the proportion of humic substances in total soil organic content being low. This reduces the availability of easily absorbable carbon, which affects the growth of the microorganisms that produce soil enzymes.

\section{Conclusions}

Technogenic salinity causes soils to form that have no natural equivalents in nature. The long-term influence of salinity significantly conditioned the properties of the studied soil. The presented results did not show unidirectional changes in the content of available $\mathrm{P}, \mathrm{K}, \mathrm{Mg}, \mathrm{Zn}, \mathrm{Cu}, \mathrm{Mn}$ and $\mathrm{Fe}$, nor in the activity of dehydrogenases, catalase, peroxidase, or alkaline and acid phosphatases in the technogenic soil. There was no reduction in activity of the tested enzymes in the soil at the soda plant (except for the S6 soil). There is also no danger of an increase in the content of available forms of the tested heavy metals in the $0-30 \mathrm{~cm}$ soil horizons.

\section{References}

Bartha, R., Bordeleau, L., 1969. Cell-free peroxidases in soil. Soil Biology Biochemistry 1(2), 139-143. http://doi.org/101016/0038-0717(69)90004-2

Bartkowiak, A., Dąbkowska-Naskręt, H., Jaworska, H., Rydlewska, M., 2020. Effect of salinity on the mobility of trace metals in soils near a soda chemical factory. Journal Elementology 25(2), 501-512. http:// doi.org/10.5601/jelem.2019.24.2.1875

Choudhary, O.P., Yaduvanshi, N.P.S., 2016. Nutrient management in saltaffected soils. Indian Journal Fertilisers 12(12), 20-35.
Cieśla, W., Dąbkowska-Naskręt, H., Siuda, W., 1981. Soil salinity state in the vicinity of the Inowrocław Soda Plant at Mątwy. Roczniki Gleboznawcze - Soil Science Annual 32(2), 103-113. (in Polish)

Crescimanno, G., Lovino, M., Provenzano, G., 1995. Influence of salinity and sodicity on soil structural and hydraulic characteristics. Soil Science Society of America Journal 59, 1701-1708. https://doi. org/10.2136/sssaj1995.03615995005900060028x

Daliakopoulos, I.N., Tsanis, I.K., Koutroulis, A., Kourgialas, N.N., Varouchakis, A.E., Karatzas, G.P., Ritsema, C.J., 2016. The threat of soil salinity: a European scale review. Science Total Environment 573, 727-739. https://doi.org/10.1016/j.scitotenv.2016.08.177

Hulisz, P., Piernik, A., 2013. Soils affected by soda industry in Inowrocław. In: Charzyński P., Hulisz P., Bednarek R. (eds.). Technogenic soils of Poland. Polish Society of Soil Science, Toruń: 125-140 (2007) Selected aspects research of salt-affected soils in Poland. SOP, Torun, 40.

Hulisz, P., Pindral, S., Kobierski, M., Charzyński, P., 2018. Technogenic layers in organic soils as a result of the impact of the soda industry. Eurasian Soil Science 51(10), 1133-1141. http://doi.org/10.1134/ S1064229318100046

Jackson, M.L., 1958. Soil chemical analysis (Constable, London).

Johnson, J.I., Temple, K.l.,1964. Some variables affecting the measurements of catalase activity in soil. Soil Science Society America Journal 28(2), 207-209. http://doi.org/10.2136/sssaj196403615995002800020024x

Khatar, M., Mohammed, M., Shekari, F., 2017. Some physiological responses of wheat and bean to soil salinity at low matric suctions. International Agrophysics 31(1), 83-91. https://doi.org/10.1515/intag2016-0028

Lemanowicz, J., 2019. Activity of selected enzymes as markers of ecotoxicity in technogenic salinization soils. Environmental Science Pollution Research 26, 13014-13024. https://doi.org/10.1007/s11356-01904830-x

Lindsay, W.L., Norvell, W.A., 1978. Development of a DTPA soil test for zinc, iron, manganese, copper. Soil Science Society of America Journal 4, 421-428. https://doi.org/10.2136/sssaj1978.03615995004200030009x

Łukasiewicz, Sz., 2012. The physical structure of the land, organic substances content, and the chemical composition of soil comprising the 
subsoil of 21 urban greenery locations in the territory of Poznań. Part IV. Content of microelements: $\mathrm{Cl}, \mathrm{Fe}, \mathrm{Mn}, \mathrm{Zn}, \mathrm{Cu}, \mathrm{B}$ and $\mathrm{Na} \mathrm{Pb}, \mathrm{Cd}$. The "EC" salinity index. Physiographic Research 63, 49-75. https://doi. org/10.2478/v10116-012-0002-7

Moraghan, J.T., Mascagni, H.J., 1991. Environmental and soil factors affecting micronutrient deficiencies and toxicities. In: Micronutrient in agriculture J.J. Mortvedt (eds.), 371-411.

Pan, C., Liu, C., Zhao, H., Wang, Y. 2013. Changes of soil physico-chemical properties and enzyme activities in relation to grassland salinization. European Journal Soil Biology 55, 13-19. https://doi.org/10.1016/ j.ejsobi.2012.09.009.

Piernik, A., Hulisz, P., 2011. Soil-plant relations in inland natural and anthropogenic saline habitats. In: Muscolo A., Flowers T.J. (eds.) Proceedings of the European COST action FA0901. European Journal Plant Science Biotechnology 5, 37-43.

PN-ISO 10390, 1997. Chemical and Agricultural Analysis - Determining soil pH. Polish Standards Committee, Warszawa.

PN-R-04020, 1994. Chemical and Agricultural Analysis. Determination of the content available magnesium. Polish Standards Committee, Warszawa.

PN-R-04022, 1996. Chemical and Agricultural Analysis - Determination of the content available potasium in mineral soils. Polish Standards Committee, Warszawa.

PN-R-04023, 1996. Chemical and Agricultural Analysis - Determination of the content of available phosphorus in mineral soils. Polish Standards Committee, Warszawa.

Polish Soil Classification $6^{\text {th }}$ edition 2019. Polish Soil Society, Committee on Genesis, Classification and Soil Cartography, UWP Wrocław-Warszawa.
Sims, J., Johnson, G., 1991. Micronutrient soil tests. In: Micronutrients in Agriculture (eds.) Mortverdt J., Cox F., Shuman L., Welch R. Soil Science Society America Journal, Madison. Wl., 427-476.

Soil Survey Laboratory Methods Manual. 1996. Soil Survey Investigation Report. USA. 42.

Tabatabai, M.A., Bremner, J.M., 1969. Use of p-nitrophenol phosphate for assay of soil phosphatase activity. Soil Biology Biochemistry 1, 301-307. https://doi.org/10.1016/0038-0717(69)90012-1

Telesiński, A., 2012. The effect of salinity on some biochemical indices of soil fertility. Water Environmental Rural Areas 12(1), 209-217.

Thalmann, A., 1968. Zur methodic derestimung der Dehydrogenaseaktivität und Boden mittels Triphenyltetrazoliumchlorid (TTC). Landwirtsch. Forsch, 21, 249-258.

Wang, M., Zheng, Q., Shen, Q., Guo, S., 2013. The critical role of potassium in plant stress response. International Journal Molecular Sciences 14, 7370-7390. https://doi.org/10.3390/ijms14047370

Widłak, M., 2016. Natural indicator of soil salinity. Proceedings of ECOpole 10(1), 359-365. https://doi.org/10.2429/proc.2016.10(1)039

Wong, V.N.L., Greene, R.S.B., Dalal, R.C., Murph, B.W., 2010. Soil carbon dynamics in saline and sodic soils: a review. Soil Use Management 26, 2-11. https://doi.org/10.1111/j.1475-2743.2009.00251.x

Xie, X., Pu, L., Zhu, M. Xu, Y., Wang, X., 2019. Linkage between soil salinization indicators and physicochemical properties in a long-term intensive agricultural coastal reclamation area, Eastern China. Journal Soils Sediments 19, 3699-3707. https://doi.org/10.1007/s11368-019-02333-3

Zhou, D., Zhulu, L., Liming, L., 2012. Regional land salinization assessment and simulation through cellular automaton-Markov modeling and spatial pattern analysis. Science Total Environment 439, 260-274. https://doi.org/10.1016/j.scitotenv.2012.09.013

\section{Słowa kluczowe}

Aktywność enzymatyczna

Przyswajalne makroelementy

i mikroelementy

Gleby technogeniczne

Gleby zasolone

\section{Zawartość przyswajalnych makro- i mikroelementów na tle aktywności enzymatycznej gleb zmienionych w wyniku oddziaływania przemysłu sodowego}

\section{Streszczenie}

Zasolenie jest jedną z głównych przyczyn degradacji środowiska glebowego. Długotrwałe zasolenie gleb wpływa na ich właściwości fizykochemiczne oraz parametry biologiczne w tym aktywność enzymatyczną. Celem pracy była ocena zawartości wybranych makro- (P, K, Mg) i mikroelementów (Zn, Cu, Mn, Fe) na tle aktywności enzymatycznej (dehydrogenaz, katalazy, peroksydazy oraz fosfatazy alkalicznej i kwaśnej) w glebach na obszarze w sąsiedztwie zakładów sodowych CIECH Soda Polska S.A. w Inowrocławiu. Próbki glebowe pobrano z powierzchniowych poziomów mineralnych gleb na głębokości 0-30 cm. Do badań wyznaczono siedem miejsc różniących się sposobem użytkowania (S1 - S6 na terenie zakładów sodowych i C - kontrola). Stwierdzono wpływ długoterminowego zasolenia na badane właściwości gleby. Zawartość dostępnych przyswajalnych form makro- i mikroskładników różniła się znacznie w zależności od miejsca pobierania próbek glebowych. Przeprowadzone badania nie wykazały jednakowych trendów zmian zawartości przyswajalnych P, K, Mg, Zn, Cu, Mn i Fe oraz aktywności dehydrogenazy, katalazy, peroksydazy oraz fosfatazy alkalicznej i kwaśnej w glebie technogenicznej. W analizowanych próbkach glebowych stwierdzono niskie zawartości form przyswajalnych wszystkich badanych mikroelementów. Wzrost zawartości soli w glebie może powodować obniżenie aktywności enzymatycznej, jednak na terenie zakładów sodowych nie wykazano takich zależności. Najniższą aktywność badanych enzymów uzyskano w glebie pobranej z miejsca S6, które zlokalizowane było w pobliżu składowisk odpadów, oczyszczalni ścieków i zakładów sodowych. 